RASĀYAN J. Chem.

Vol. 11 | No. 4 |1765 - 1770| October - December | 2018 ISSN: 0974-1496 | e-ISSN: 0976-0083 | CODEN: RJCABP http://www.rasayanjournal.com http://www.rasayanjournal.co.in

\title{
SYNTHESIS AND ANTIOXIDANT ACTIVITY OF PRENYLATED RESVERATROL
}

\author{
Tagor Marsillam Siregar ${ }^{1,2, *}$, Emil Budianto ${ }^{2}$, Herry Cahyana ${ }^{2}$ \\ and Widajanti Wibowo ${ }^{2}$ \\ ${ }^{1}$ Laboratory of Chemistry, Food Technology Department, Faculty of Science and Technology, \\ Universitas Pelita Harapan, Lippo Karawaci, Tangerang 15811, Indonesia \\ ${ }^{2}$ Postgraduates Program, Department of Chemistry, Faculty of Mathematics and Natural \\ Sciences, Universitas Indonesia, Depok 16424, Indonesia \\ *E-mail : tagor.siregar@uph.edu
}

\begin{abstract}
Resveratrol derivatives have been reported to have important bioactivities. Synthesis of monomeric resveratrol derivatives has been a challenging topic in both organic and medicinal chemistry. A Synthesis of prenylated resveratrol was developed through prenylation between resveratrol (3,5,4'-trihydroxystilbene) and prenyl bromide (3,3-dimethyl allyl bromide) using heterogeneous superbase catalyst $\gamma-\mathrm{Al}_{2} \mathrm{O}_{3} / \mathrm{NaOH} / \mathrm{Na}$. The aim of this research is to obtain prenylated resveratrol compound that has important bioactivity and to identify a type of prenylation, $\mathrm{O}$ - or C-prenylation. Characterization of the product was carried out using liquid chromatography-mass spectrometry (LC-MS) and nuclear magnetic resonance $\left({ }^{1} \mathrm{H}-\mathrm{NMR}\right)$. The antioxidant activity of the samples was determined using DPPH radical scavenging assay. The results of LC-MS analysis of the product showed the molecular ion peak at $\mathrm{m} / \mathrm{z} 365.38[\mathrm{M}+\mathrm{H}]^{+}$that indicated the presence of prenylated resveratrol with two prenyl $\left(\mathrm{C}_{5} \mathrm{H}_{9-}\right)$ substituent. The ${ }^{1} \mathrm{H}-\mathrm{NMR}$ spectrum of the product indicated that the addition of two prenyl substituent occurs at the hydroxyl group on the structure of resveratrol (O-prenylation). Prenylation caused decreasing free radical scavenging activity of the product $\left(\mathrm{IC}_{50}=102,75 \mathrm{ppm}\right)$ compared to resveratrol $\left(\mathrm{IC}_{50}=63,52 \mathrm{ppm}\right)$ and it means that the addition of prenyl substituents occurs through O-prenylation.

Keywords: Antioxidant activity, Prenylation, Prenyl bromide, Prenylated resveratrol, Resveratrol, Superbase catalyst $\gamma-\mathrm{Al}_{2} \mathrm{O}_{3} / \mathrm{NaOH} / \mathrm{Na}$
\end{abstract}

(C) RASĀYAN. All rights reserved

\section{INTRODUCTION}

Resveratrol (3,5,4'-trans-trihydroxystilbene) and its derivatives belong to a group of plant polyphenolic compound "stilbene", which has a molecular structure in the form of two phenyl rings linked by an ethylene bridge ${ }^{1}$. Resveratrol and its derivatives have been found in particular families of plants including Vitaceae, Dipterocarpaceae, Gnetaceae, Cyperaceae, Leguminosae, Moraceae, Pinaceae and Polygonaceae ${ }^{2-10}$. The biosynthesis of resveratrol in-plant is catalyzed by stilbene synthase. Resveratrol that has formed subsequently undergo structure modifications through glycosylation, methylation, oligomerization, isomerization, and prenylation generate various resveratrol derivatives with intriguing chemical diversity ${ }^{11-16}$. Resveratrol derivatives have been reported to have important bioactivities. Therefore, Synthesis of monomeric resveratrol derivatives has been a challenging topic in both organic and medicinal chemistry. In recent years, a number of catalytic methods have been developed to generate chemical diversity synthetically ${ }^{16,17}$. Prenylation plays a major role in the diversification of aromatic natural products, such as phenylpropanoids, flavonoids, and coumarins ${ }^{18}$. Prenylation is a chemical or enzymatic addition of a hydrophobic isoprenoid side chain to an accepting molecule such as a flavonoid or polyhydroxy aromatic compound ${ }^{19}$. Polyphenols such as flavonoid and stilbenoid have been reported to possess isoprenoid group on its structure ${ }^{20}$. These prenylated polyphenols have diverse and significant

Rasayan J. Chem., 11(4), 1765-1770(2018)

http://dx.doi.org/10.31788/RJC.2018.1143051




bioactivities such as antioxidant, antibacterial, antitumor, antityrosinase and anticancer activities ${ }^{21-23}$. The addition of a prenyl residue to polyphenol skeletons may contribute to the enhancement of the biological activities of polyphenolic compounds ${ }^{23,24}$.

Synthesis of prenylated resveratrol was carried out through prenylation between resveratrol (3,5,4'-trihydroxystilbene) and prenyl bromide (3,3-dimethyl allyl bromide) using heterogeneous superbase catalysts $\gamma-\mathrm{Al}_{2} \mathrm{O}_{3} / \mathrm{NaOH} / \mathrm{Na}$. In the previous study, we had obtained the optimal condition of prenylation $^{25}$. The aim of this study is to obtain prenylated resveratrol which has been known to have important bioactivities and also to get confirmation whether the addition of prenyl substituents occurs on $\mathrm{C}$ - (aromatic ring) or $\mathrm{O}-(-\mathrm{OH}$ groups) atoms of resveratrol structure.

\section{Materials}

\section{EXPERIMENTAL}

resveratrol (3,5,4'-trihydroxystilbene) (Sigma Aldrich), prenyl bromide (3,3-dimethyl allyl bromide) (Merck), Sodium metal (Department of Chemistry University of Indonesia), $\gamma-\mathrm{Al}_{2} \mathrm{O}_{3}$, methanol, ethanol, acetone, ethyl acetate, $\mathrm{NaOH}, \mathrm{N}_{2}$ gas (99.9\% extra pure), DPPH (2,2-diphenyl-1-picrylhydrazyl). All chemicals used were of analytical grade.

\section{Synthesis of Prenylated Resveratrol}

The superbase catalyst $\gamma-\mathrm{Al}_{2} \mathrm{O}_{3} / \mathrm{NaOH} / \mathrm{Na}$ was prepared in the previous study ${ }^{25} \cdot \gamma-\mathrm{Al}_{2} \mathrm{O}_{3} / \mathrm{NaOH} / \mathrm{Na}$ is a heterogeneous catalyst that has characterized as solid phase catalyst. Prenylation Reaction was conducted by using the superbase catalyst $\gamma-\mathrm{Al}_{2} \mathrm{O}_{3} / \mathrm{NaOH} / \mathrm{Na}$ in acetone solvent. $2 \mathrm{mg}$ resveratrol $\left(\mathrm{C}_{14} \mathrm{H}_{12} \mathrm{O}_{3}\right)$ was reacted with $0.01 \mathrm{ml}$ prenyl bromide $(\mathrm{d}=1,29 \mathrm{~g} / \mathrm{ml} ; \mathrm{Mr}=149,029 \mathrm{~g} / \mathrm{mol})$ in $8 \mathrm{ml}$ acetone and then refluxed for 4 hours at $60^{\circ} \mathrm{C}$. The product was separated from the catalyst using filter paper, purified with preparative thin layer chromatography and subsequently characterized using LC-MS and ${ }^{1} \mathrm{H}-\mathrm{NMR}$ analysis to confirm the presence of prenylated resveratrol.

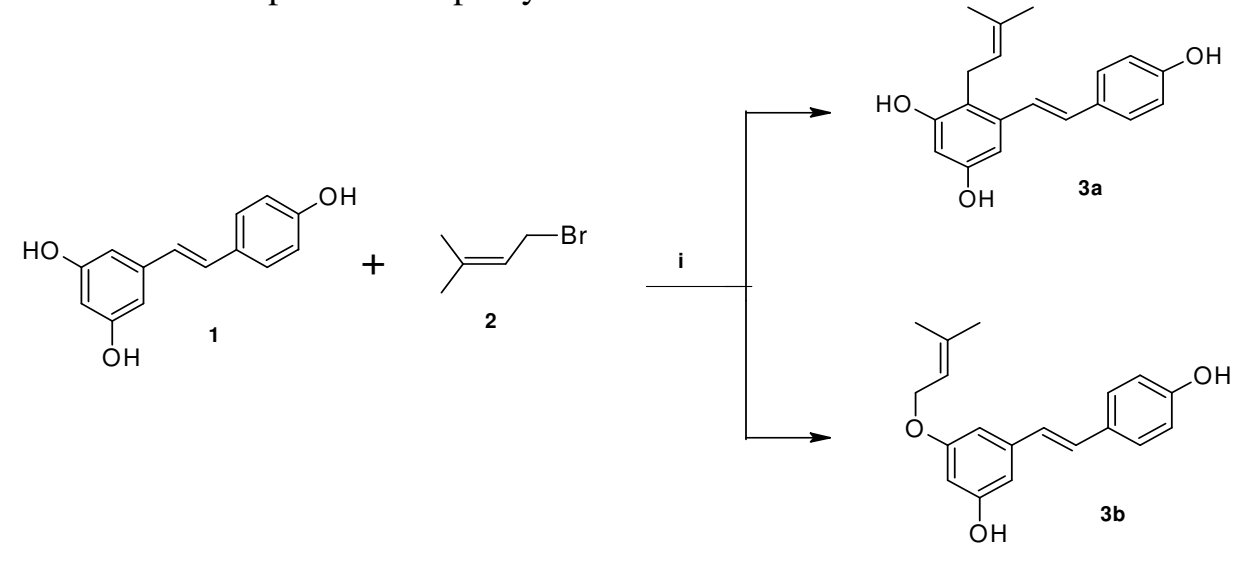

Fig.-1: The Proposed of Prenylation of Resveratrol ${ }^{25}$ (1): Prenyl Bromide (3,3-dimethyl allyl bromide) (2); and

Prenylated Resveratrol (3a and 3b) : (i) Superbase catalyst $\gamma-\mathrm{Al}_{2} \mathrm{O}_{3} / \mathrm{NaOH} / \mathrm{Na}$, acetone, reflux, $60^{\circ} \mathrm{C}$, $4 \mathrm{~h}$

\section{LC-MS (Liquid Chromatography-Mass Spectrometry) Analysis}

LC-MS analysis was carried out on an LC-MS Mariner Biospectrometry instrument (LC : Hitachi L 6200), ESI (Electron Spray Ionization) System. LC (Liquid Chromatography) used C18 super column. The mobile phase consisted of solution A (aquadest that contained $0.3 \% \mathrm{CH}_{3} \mathrm{COOH}$ ) and solution $\mathrm{B}$ (methanol that contained $0.3 \% \mathrm{CH}_{3} \mathrm{COOH}$ ), Flow rate: $0.1 \mathrm{ml} /$ minutes, injection volume: $20 \mu \mathrm{l}$ and temperature of the column was controlled based on room temperatures $\left(28^{0} \mathrm{C}\right)$. The MS used positive ion mode $(\mathrm{m} / \mathrm{z} 100-1200)$.

\section{${ }^{1}$ H-NMR (Nuclear Magnetic Resonance) Analysis}

${ }^{1} \mathrm{H}$ spectrum was measured by using JEOL ECA-500 NMR (Nuclear Magnetic Resonance) Spectrometers that used radio frequency $500 \mathrm{MHz}$. 


\section{Free Radical Scavenging Activity (DPPH)}

Free radical scavenging activity of the product of prenylation was determined using 2,2-diphenyl-1picrylhydrazyl (DPPH) assay procedure described by Amin and Lee ${ }^{26}$. DPPH is a stable free radical, which forms a purple-colored solution when dissolved in methanol. Antioxidant components can scavenge this stable free radical. One milliliter of $0.2 \mathrm{mM}$ DPPH methanol solution was added to $4 \mathrm{~mL}$ of a methanolic solution of various sample concentrations, mixed well, vortex and kept at room temperature in dark $30 \mathrm{~min}$. The absorbance was measured at $517 \mathrm{~nm}$ against an appropriate blank.

$\%$ Radical Scavenging $=\left(\mathrm{A}_{0}-\mathrm{A}\right) / \mathrm{A}_{0}$, Where $\mathrm{A}_{0}=$ Absorbance of control $; \mathrm{A}=$ Absorbance of test sample.The $\mathrm{IC}_{50}$ values (concentration of sample required to scavenge $50 \%$ of free radicals) were calculated by the regression equation prepared from various sample concentrations of methanolic solutions.

\section{RESULTS AND DISCUSSION}

Prenylation had carried out through a reaction between phenol derivatives and prenyl bromide (3,3-dimethyl allyl bromide) by using a base catalyst such as $\mathrm{NaOH}$ and $\mathrm{K}_{2} \mathrm{CO}_{3}$, in which the addition of prenyl group could occur on C- or O- atoms position of its structure ${ }^{27}$. In this research, the addition of prenyl (3,3-dimethyl allyl bromide) group to resveratrol was carried out by using a superbase catalyst $\gamma-\mathrm{Al}_{2} \mathrm{O}_{3} / \mathrm{NaOH} / \mathrm{Na}$. Resveratrol $\left(\mathrm{C}_{14} \mathrm{H}_{12} \mathrm{O}_{3}\right)$ is a phenol derivative compound, therefore the addition of prenyl group could be occured on its structure.The product was obtained in yellowish solution form and subsequently characterized using spectroscopy methods such as LC-MS and ${ }^{1} \mathrm{H}-\mathrm{NMR}$ analysis to confirm the presence of prenylated resveratrol.

\section{LC-MS Analysis}

The identification of prenylated resveratrol was carried out by comparison with the pure standard (resveratrol). LC chromatogram of the product of prenylation and resveratrol (standard) is shown in figure 2. There are two major peaks with RT (retention time) 3.13 and 10.60 minutes detected in the chromatogram of the product. The peak with RT 3.13 was identified as a peak of resveratrol while the peak with RT 10.60 was identified as a peak of the prenylated resveratrol. ESI-MS spectrum for the peak with RT 3.13 showed the presence of ion peak $\mathrm{m} / \mathrm{z} 229.2[\mathrm{M}+\mathrm{H}]^{+}$that corresponded to adduct ion peak $\mathrm{m} / \mathrm{z} 251.2[\mathrm{M}+\mathrm{Na}]^{+}$and $\mathrm{m} / \mathrm{z} 261.4\left[\mathrm{M}+\mathrm{CH}_{3} \mathrm{OH}+\mathrm{H}\right]^{+}$. This spectrum has similarity with resveratrol (standard) spectrum. It could explain that the peak with RT 3.13 was identified as a resveratrol that had a monoisotopic mass of 228.0786.

ESI-MS spectrum for peak with RT 10.60 showed the presence of ion peak $\mathrm{m} / \mathrm{z} 365.3[\mathrm{M}+\mathrm{H}]^{+}$and this peak corresponded to adduct ion peak $\mathrm{m} / \mathrm{z} 123.1[\mathrm{M}+\mathrm{H}]^{3+} ; \mathrm{m} / \mathrm{z} 137.1[\mathrm{M}+\mathrm{H}+2 \mathrm{Na}]^{3+}$; $\mathrm{m} / \mathrm{z} 191.2\left[\mathrm{M}+\mathrm{H}+\mathrm{NH}_{4}\right]^{2} ; \mathrm{m} / \mathrm{z} 387.4[\mathrm{M}+\mathrm{Na}]^{+}$and $\mathrm{m} / \mathrm{z} 403.5[\mathrm{M}+\mathrm{K}]^{+}$. Ion peak $\mathrm{m} / \mathrm{z} 123.1[\mathrm{M}+\mathrm{H}]^{3+}$ is a base peak and $M=364$. These data suggest that the prenylated resveratrol had been formed as a product of the reaction. $\mathrm{M}=364$ indicates a resveratrol which is substituted with two prenyl group due to resveratrol and prenyl $\left(\mathrm{C}_{5} \mathrm{H}_{9-}\right)$ had molecular mass 228 and 69 respectively.

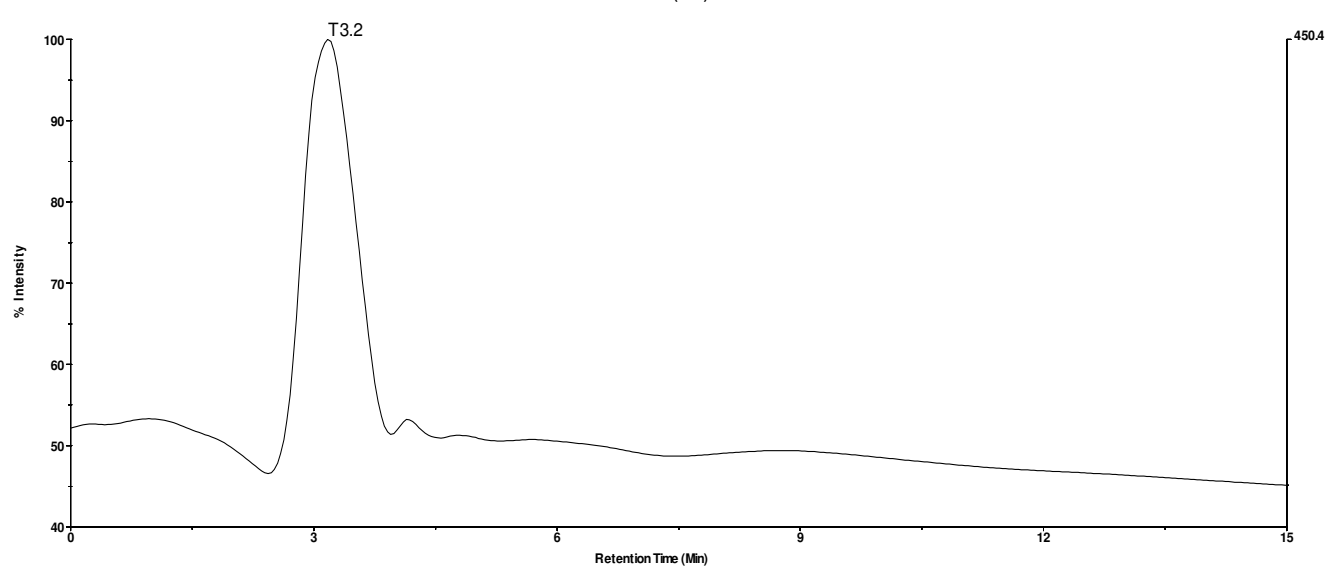


RASĀYAN J. Chem.

Vol. 11 | No. 4 |1765 - 1770| October - December | 2018



(b)

Fig.-2: (a) LC chromatogram of resveratrol (standard)

(b) LC chromatogram of the product of prenylation of resveratrol

\section{${ }^{1}$ H-NMR (Nuclear Magnetic Resonance) Analysis}

The ${ }^{1} \mathrm{H}-\mathrm{NMR}$ spectrum was used to give confirmation about the presence of prenylated resveratrol and also to know whether the prenylation occurred on $\mathrm{C}$ - or $\mathrm{O}$ - atoms in resveratrol's structure. The identification of prenylated resveratrol was carried out by comparison ${ }^{1} \mathrm{H}-\mathrm{NMR}$ spectrum with the resveratrol (standard). The ${ }^{1} \mathrm{H}-\mathrm{NMR}$ spectrum of resveratrol and the product could be seen in table 1 . Either resveratrol (standard) or the product showed similar aromatic proton signals, but the product also showed a strong signal indicating O-prenylation.

Table-1: ${ }^{1} \mathrm{H}-\mathrm{NMR}$ Spectrum Data

\begin{tabular}{c|c|c}
\hline \multirow{2}{*}{ Carbon Position } & \multicolumn{2}{|c}{${ }^{1} \mathrm{H}-\mathrm{NMR}$ Spectrum $(\delta$ in ppm and $J$ values $(\mathrm{Hz}))$} \\
\cline { 2 - 3 } & Resveratrol (standard) & Product of Prenylation \\
\hline 4 & $6.26(1 \mathrm{H}, \mathrm{t}, J=1.9)$ & $6.27(1 \mathrm{H}, \mathrm{t}, J=2.0)$ \\
\hline 2,6 & $6.53(2 \mathrm{H}, \mathrm{d}, J=1.9)$ & $6.54(2 \mathrm{H}, \mathrm{d}, J=2.0)$ \\
\hline 11,13 & $6.83(2 \mathrm{H}, \mathrm{d}, J=9)$ & $7.01(2 \mathrm{H}, \mathrm{d}, J=5.2)$ \\
\hline 7 & $6.88(1 \mathrm{H}, \mathrm{d}, J=16.2)$ & $7.07(1 \mathrm{H}, \mathrm{d}, J=16.2)$ \\
\hline 8 & $7.01(1 \mathrm{H}, \mathrm{d}, J=16.9)$ & $7.19(1 \mathrm{H}, \mathrm{d}, J=16.2)$ \\
\hline 10,14 & $7.42(2 \mathrm{H}, \mathrm{d}, J=9)$ & $7.40(2 \mathrm{H}, \mathrm{d}, J=6.5)$ \\
\hline $1^{\prime}, 1^{\prime}$, & - & $4.57(4 \mathrm{H}, \mathrm{d}, J=5.2)$ \\
\hline $2^{\prime}, 2^{\prime}$, & - & $5.29-5.46(2 \mathrm{H}, \mathrm{m})$ \\
\hline $3^{\prime}, 3^{\prime}$, & - & - \\
\hline $4^{\prime}, 4^{\prime}$, & - & $1.63(6 \mathrm{H}, \mathrm{s})$ \\
\hline $5^{\prime}, 5^{\prime}$ & - & $1.76(6 \mathrm{H}, \mathrm{s})$ \\
\hline
\end{tabular}

The ${ }^{1} \mathrm{H}$-NMR spectrum displayed signals indicating a 1,3,5-trisubstituted aromatic ring, resveratrol (standard) showed signals at $\delta_{\mathrm{H}} 6.26(1 \mathrm{H}, \mathrm{t}, J=1.9 \mathrm{~Hz}, \mathrm{H}-4)$ and $\delta_{\mathrm{H}} 6.53(2 \mathrm{H}, \mathrm{d}, J=1.9 \mathrm{~Hz}, \mathrm{H}-2,6)$ while the product of prenylation showed signals at $\delta_{\mathrm{H}} 6.27(1 \mathrm{H}, \mathrm{t}, J=2.0 \mathrm{~Hz}, \mathrm{H}-4)$ and $\delta_{\mathrm{H}} 6.54(2 \mathrm{H}, \mathrm{d}, J=2.0$ $\mathrm{Hz}, \mathrm{H}-2,6)$. The spectrum of the second ring indicates a 1',4'-disubstituted aromatic ring, resveratrol (standard) showed signals at $\delta_{\mathrm{H}} 6.83\left(2 \mathrm{H}, \mathrm{d}, J=9 \mathrm{~Hz}, \mathrm{H}-3^{\prime}, 5^{\prime}\right)$ and $\delta_{\mathrm{H}} 7.42\left(2 \mathrm{H}, \mathrm{d}, J=9 \mathrm{~Hz}, \mathrm{H}-2^{\prime}, 6^{\prime}\right)$ while product of prenylation showed signals at7.01 $\left(1 \mathrm{H}, \mathrm{d}, J=5.2 \mathrm{~Hz}, \mathrm{H}-3^{\prime}, 5^{\prime}\right)$ and $\delta_{\mathrm{H}} 7.40(2 \mathrm{H}, \mathrm{d}, J=6.5 \mathrm{~Hz}$, $\mathrm{H}-2$ ',6'). The ${ }^{1} \mathrm{H}-\mathrm{NMR}$ spectrum also showed signals indicating $E$-double bond, resveratrol (standard) at $\delta_{\mathrm{H}} 6.88(1 \mathrm{H}, \mathrm{d}, J=16.2 \mathrm{~Hz}, \mathrm{H}-\mathrm{a})$ and $\delta_{\mathrm{H}} 7.01(1 \mathrm{H}, \mathrm{d}, J=16.9 \mathrm{~Hz}, \mathrm{H}-\mathrm{b})$, while the product of prenylation at $\delta_{\mathrm{H}} 7,07(1 \mathrm{H}, \mathrm{d}, J=16.2 \mathrm{~Hz}, \mathrm{H}-\mathrm{a})$ and $\delta_{\mathrm{H}} 7.19(1 \mathrm{H}, \mathrm{d}, J=16.2 \mathrm{~Hz}, \mathrm{H}-\mathrm{b})$. The product of synthesis showed signals that do not exist in resveratrol (standard), these signals has been identified as two prenyl substituent [four methyls at $\delta_{\mathrm{H}} 1.63\left(6 \mathrm{H}, \mathrm{s}, \mathrm{H}-4{ }^{\prime}, 4{ }^{\prime},{ }^{\prime}\right)$ and $\delta_{\mathrm{H}} 1.76(6 \mathrm{H}, \mathrm{s}, \mathrm{H}-5$ ',, 5 ', '), two olefinic protons at $\delta_{\mathrm{H}} 5.29-5.46\left(2 \mathrm{H}, \mathrm{m}, \mathrm{H}-2\right.$ ',, 2 ' ') and four methylene protons at $\delta_{\mathrm{H}} 4.57(4 \mathrm{H}, \mathrm{d}, J=5.2 \mathrm{~Hz}$, 
H-1", 1", )]. The increased chemical shift observed by the methylene protons of the prenyl group indicates that the phenyl group was introduced to an oxygen atom (O-prenylation).

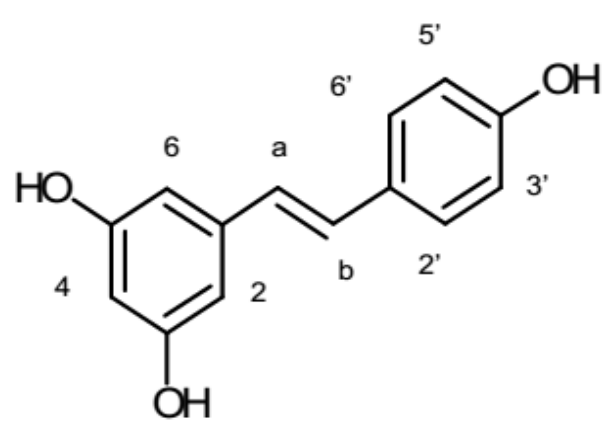

(a)

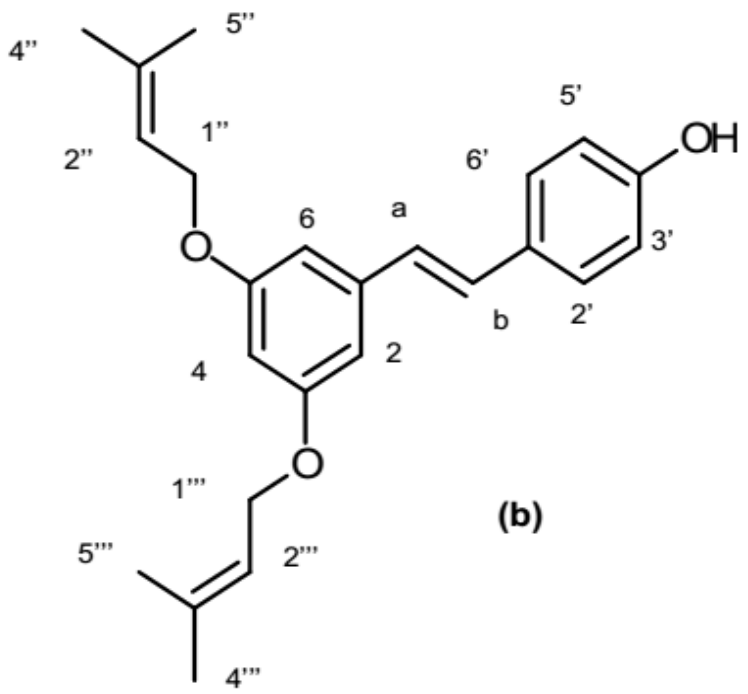

Fig.-3: (a) Resveratrol, (b) The proposed Structure of Prenylated Resveratrol

\section{Free Radical Scavenging Activity}

The data of free radical scavenging activity in Table-2 shows that the product has higher $\mathrm{IC}_{50}$ value than resveratrol. The increasing of the $\mathrm{IC}_{50}$ value indicated that the decreasing of free radical scavenging activity of the product had occurred.

Table-2: Free Radical Scavenging Activity

\begin{tabular}{cc}
\hline Sample & $\mathrm{IC}_{50}(\mathrm{ppm})$ \\
\hline Resveratrol & 63.52 \\
Product of Synthesis & 102.75 \\
\hline
\end{tabular}

The decreasing in free radical scavenging activity was caused by the effect of the introduction of O-prenyl substituents to resveratrol structure. $-\mathrm{OH}$, groups in aromatic compounds have been known to play an important role in free radical scavenging activity. Therefore, loosing of hydroxyl groups on the resveratrol structure caused a reduction in free radical scavenging activity. This result in line with AbuMellal et al ${ }^{27}$. that reported 5,4'-dihydroxy-3-prenyloxy-E-stilbene an O-prenylated resveratrol $\left(\mathrm{IC}_{50} 60.3 \mu \mathrm{M}\right)$ experienced an almost two-fold reduction in DPPH scavenging activity compared with resveratrol $\left(\mathrm{IC}_{50} 31.4 \mu \mathrm{M}\right)$.

\section{CONCLUSION}

A Synthesis of prenylated resveratrol was developed through prenylation between resveratrol $(3,5,4$ 'trihydroxystilbene) and prenyl bromide (3,3-dimethyl allyl bromide) using heterogeneous superbase catalyst $\gamma-\mathrm{Al}_{2} \mathrm{O}_{3} / \mathrm{NaOH} / \mathrm{Na}$. According to LC-MS analysis, the prenylated resveratrol was identified as a molecular ion peak at $\mathrm{m} / \mathrm{z} 365.38[\mathrm{M}+\mathrm{H}]^{+}$that indicated the presence of prenylated resveratrol with two prenyl $\left(\mathrm{C}_{5} \mathrm{H}_{9}-\right)$ unit. The ${ }^{1} \mathrm{H}-\mathrm{NMR}$ spectrum of the product indicated that the addition of two prenyl substituent occurs at the hydroxyl group on the structure of resveratrol (O-prenylation). Prenylation caused decreasing free radical scavenging activity of the product $\left(\mathrm{IC}_{50}=102.75 \mathrm{ppm}\right)$ compared to resveratrol $\left(\mathrm{IC}_{50}=63.52 \mathrm{ppm}\right)$ and it means that the addition of prenyl substituents occurs through O-prenylation. It is suggested to carry out other bioactivities assays such as antibacterial, antiinflammation and anticancer activity for proving that there is increasing bioactivity in the prenylated resveratrol.

\section{REFERENCES}

1. J. Condori, G. Sivakumar, J. Hubstenberger, M.C. Dolan, V.S. Sobolev and F. Medina-Bolivar, Plant Physiol.Biochem., 48, 310 (2010), DOI:10.1016/j.plaphy.2010.01.008. 
RASĀYAN $J$. Chem.

Vol. 11 | No. 4 |1765 - 1770| October - December | 2018

2. R.E. King, J.A. Bomser and D.B. Min, Compr. Rev. Food Sci. F, 5, 65 (2006), DOI: 10.1111/j.15414337.2006.00001.x.

3. C.F Wu, J.Y. Yang, F. Wang and X.X. Wang, Chin. J. Nat. Med., 11, 0001 (2013).

4. C. Riviêre, A.D. Pawlus and J.M. Mêrillon, Nat. Prod. Rep., 29, 1317 (2012), DOI: $10.1039 / \mathrm{C} 2 \mathrm{NP} 20049 \mathrm{~J}$.

5. K.S. Huang, Y.H. Wang, R.L. Li and M. Lin, Phytochemistry, 54, 875 (2000), DOI: 10.1016/S00319422(00)00151-5.

6. I. Iliya, Z. Ali, T. Tanaka, M. Inuma, M. Furusawa, K. Nakaya, J. Murata and D.Darnaedi, Phytochemistry, 61, 959 (2002).

7. I. Iliya, Z. Ali, T. Tanaka, M. Inuma, M.Furusawa, K. Nakaya, J. Murata, D. Darnaedi, N. Matsuura, and M. Ubukata, Phytochemistry, 62, 601 (2003).

8. W. Xiang, B. Jiang, X.M. Li, H.J. Zhang, Q.S. Zhao, S.H. Li and H.D. Sun, Fitoterapia, 73, 40 (2002), DOI: $10.1016 / \mathrm{S} 0367-326 \mathrm{X}(01) 00370-7$.

9. K. Xiao, H.J. Zhang, L.J. Xuan, J. Zhang, Y.M. Xu and D.L. Bai, Chemistry, 34, 453 (2008).

10. E. Kato, Y. Tokunaga and F. Sakan, J. Agric. Food Chem., 57, 2544 (2009), DOI: 10.1021/jf803077p.

11. V.S. Sobolev, T.L. Potter and B.W. Horn, Phytochem. Analysis, 17, 312 (2006), DOI: 10.1002/pca.920.

12. G.J. Fan, X.D. Liu, Y.P. Qian, Y.J. Shang, X.Z. Li, F. Dai, J.G. Fang, X.L. Jin and B. Zhou, J.Bioorg. Med. Chem., 17, 2360 (2009), DOI: 10.1016/j.bmc.2009.02.014.

13. H. Piotrowska, M. Kucinska and M. Murias, Mutat. Res., 750, 60(2012), DOI: 10.1016/j.mrrev.2011.11.001.

14. Sahidin, E.H. Hakim, Y.M. Syah, L.D. Juliawaty, S.A. Achmad, L. Din and J. Latip, Indo. J. Chem, 8 (2), 245 (2008), DOI:10.22146/ijc.21629

15. P.Saiko, A. Szakmary, W. Jaeger and T. Szekeres, Mutat. Res., 658, 68 (2008), DOI:10.1016/j.mrrev.2007.08.004.

16. S. He and X. Yan, Curr. Med. Chem., 20, 1005 (2013), DOI:10.2174/092986713805288941.

17. L. Chen, J. Zhao, S. Yin and C.T. Au, The Royal Society Of Chemistry, Advances, 3, 3799 (2013), DOI: $10.1039 / \mathrm{C} 2 \mathrm{RA} 22252 \mathrm{C}$.

18. K. Yazaki, K. Sasaki K and Y. Tsurumaru, Phytochemistry, 70, 1739 (2009), DOI:10.1016/j.phytochem.2009.08.023.

19. N. Koolaji, A. Abu-Mellal, V.H. Tran, R.K. Duke and C.C. Duke, Eur. J. Med. Chem., 63, 415 (2013), DOI: 10.1016/j.ejmech.2013.02.017

20. M. Ohyama, T. Tanaka, J. Yokoyama and M. Iinuma, Biochem. Syst. Ecol., 23(6), 669 (1995), DOI: 10.1016/0305-1978(95)00056-9

21. M. Osorio, J. Aravena, J. Vergara, L. Taborga, E. Baeza and K. Catalán, Molecules, 17, 556 (2012), DOI:10.3390/molecules 17010556

22. L. Pisco, M. Kordian, K. Peseke, H. Feist, D. Michalik and E. Estrada, Eur. J. Med. Chem., 41, 401 (2006), DOI:10.1016/j.ejmech.2005.10.020

23. M.M.M. Pinto, M.E. Sousa and M.S.J. Nascimento, Curr. Med. Chem., 12(21), 2517 (2005), DOI: 10.2174/092986705774370691

24. R.A.P. Castanheiro, A.M.S. Silva, N.A.N. Campos, M.S.J. Nascimento and M.M.M. Pinto, Pharmaceuticals, 2, 33 (2009), DOI:10.3390/ph2020033

25. T.M. Siregar, H. Cahyana and W. Wibowo, J. Chem. Pharma. Res., 6(10), 349 (2014).

26. I. Amin and W.Y Lee, J. Sci. Food. Agric., 85(13): 2314 (2005), DOI:10.1002/jsfa.2261

27. A. Abu-Mellal, N. Koolaji, R.K. Duke, V.H. Tran and C.C. Duke, Phytochemistry, 77, 251 (2012), DOI:10.1016/j.phytochem.2012.01.012.

[RJC-3051/2018] 